УДК $167+376+37.037$

DOI https://doi.org/10.24919/2308-4863/42-1-45

\title{
Наталія ЛЕЩЦЙ,
}

orcid.org/0000-0002-8843-7156

кандидат педагогічних наук, доиент,

доиент кафедри дефектологї та фізичної реабілітаиї

Південноукрайнського наиіонального педагогічного університету імені К. Д. Ушинського

(Oдеса, Україна)lleschiy@ukr.net

\section{ХАРАКТЕРИСТИКА ФІЗКУЛЬТУРНО-ОЗДОРОВЧОЇ ПРОГРАМИ В ДІТЕЙ СЕРЕДНЬОГО ШКІЛЬНОГО ВІКУ ЗІ СКЛАДНИМИ ПОРУШЕННЯМИ РОЗВИТКУ В УМОВАХ НАВЧАЛЬНО-РЕАБІЛІТАЦІЙНОГО ЦЕНТРУ}

\begin{abstract}
Стаття присвячена проблемі застосування засобів фізкультурно-оздоровчої програми в дітей середнього шкільного віку зі складними порушеннями розвитку. Мета роботи полягає в обтрунтуванні фізкультурно-оздоровчої програми в дітей середнього шкільного віку зі складними порушеннями розвитку. Матеріал дослідження та його методи: методи теоретичного рівня дослідження (аналіз, синтез, індукиія, дедукиія). У дослідженні брали участь 90 дітей середнього шкільного віку зі складними порушеннями розвитку (порушення інтелекту та слуху). Розроблено фізкультурно-оздоровчу програму для дітей середнього шкільного віку зі складними порушеннями розвитку, щчо включала раціональне поєднання вправ різного спрямування; дотримання оптимальної їх інтенсивності та тривалості виконання відповідно до індивідуальних особливостей дитини зі складними порушеннями розвитку; вихідного положення; супутніх захворювань та факторної структури загального рівня фізичного здоров'я дітей. Реалізація фізкультурно-оздоровчої програми здійснювалася протягом дев'яти місяиів і поділялася на три послідовні періоди: підготовчий, тренувальний та підтримувальний, з виокремленням засобів і методів відповідно до періодів. Зміст програми передбачав наявність спечіальних комплексів фізичних вправ, які сприяли фізичному розвитку та поліпшенню здоров'я дітей відповідно до порушень їхнього фізичного розвитку. У рамках фізкультурно-оздоровчої роботи в навчально-реабілітаційному иентрі розроблено інноваційну фізкультурно-оздоровчу програму для дітей середнього шкільного віку зі складними порушеннями розвитку, яка відрізнялася диферениійованим підходом у ретламентаиії фізичного навантаження та підборі засобів відповідно до рівня фізичного здоров'я дитини зі складними порушеннями розвитку й етапу занять.

Ключові слова: фізкультурно-оздоровча програма, навчально-реабілітаційний ичентр, діти зі складними порушеннями розвитку.
\end{abstract}

Nataliia LESHCHII, orcid.org/0000-0002-8843-7156 Ph. D., Associate Professor, Associate Professor at the Department of Defectology and Physical Rehabilitation South Ukrainian National Pedagogical University named after K. D. Ushynsky (Odesa, Ukraine) lleschiy@ukr.net

\section{CHARACTERISTICS OF THE PHYSICAL CULTURE AND HEALTH PROGRAM IN MIDDLE SCHOOL AGE CHILDREN WITH COMPLEX DEVELOPMENTAL DISORDERS IN THE CONDITIONS OF EDUCATIONAL AND REHABILITATION CENTER}

Formulation of the problem. The article is devoted to the problem of application of means of the physical culture and health program in middle school age children with complex developmental disorders in the conditions of educational and rehabilitation center. The purpose of the study is to substantiate the physical culture and health program for middle school age children with complex developmental disorders. Research material and its methods: methods of theoretical level of research (analysis, synthesis, induction, deduction). The study involved 90 middle school children with complex developmental disorders (intelligence and hearing impairment). Results. Physical culture and health program for children with complex developmental disorders was developed that included a rational combination of exercises of different directions; adherence to their optimal intensity and duration of performance in accordance with the individual characteristics of the child with complex developmental disorders; the starting position; comorbidities and the factor structure of the overall level of physical health of children. The implementation of the physical culture and health program was carried out for nine months and was divided into three consecutive periods: preparatory, training and maintenance with the separation of tools and methods according to the periods. The content of the program provided for the presence 
Аещій Н. Характеристика фізкультурно-оздоровчої програми в дітей середнього шкільного віку...

of special sets of physical exercises that contributed to the physical development and improvement of children's health in accordance with the violations of their physical development. Conclusions. As part of physical culture and health work in the educational and rehabilitation center innovative physical culture and health program was developed for middle school children with complex developmental disorders, which differed in a differentiated approach to regulating physical activity and selection of means according to the level of physical health of a child with complex developmental disorders.

Key words: physical culture and health program, educational and rehabilitation center, children with complex developmental disorders.

Постановка проблеми. Багатоманітність сполучуваності рухових, сенсорних, мовленнєвих та інтелектуальних особливостей розвитку спричинює різноманітні бар'єри у процесі навчання і виховання дітей зі складними порушеннями розвитку. Діти зі складними порушеннями розвитку мають поєднання двох і більше порушень, які тісно корелюють одне 3 одним, утворюють унікальні комплекси проявів, що негативно позначаються на цілісному розвитку організму дитини, спонукають до нових наукових пошуків для вирішення цієї проблеми (Лещій, 2020: 15). Аналіз результатів сучасних досліджень онтогенезу інтегративної діяльності функціональних систем організму дитини переконливо свідчить про провідну роль рухового аналізатора у створенні компенсаторної основи для продуктивного подолання обмежень функціонування (Бобренко, 2011: 23). Саме тому одним із засобів успішної реабілітації та подальшої соціалізації дітей зі складними порушеннями розвитку є використання оздоровчого потенціалу фізичної культури, функція якої полягає у формуванні в дітей відповідних умінь і навичок, стимулюванні їхньої пізнавальної активності, забезпеченні набуття досвіду практичної діяльності і спілкування (Лещій, 2020: 100).

Аналіз досліджень. Фізкультурно-оздоровча складова частина освітнього процесу дітей, які мають складні порушення розвитку, суттєво відрізняється від комплексу заходів, що традиційно використовуються у спеціальних закладах освіти для дітей із певним типом порушення або більшості закладів з інклюзивним навчанням (Ляхова, 2007: 30). Специфіка іï організації зумовлена регламентом функціонування навчально-реабілітаційного центру (далі - НРЦ), у якому забезпечуються індивідуальний догляд та супровід учнів / вихованців зі складними порушеннями 3 метою здобуття ними освіти або пропонуються абілітаційні/реабілітаційні, корекційно-розвиткові та психолого-педагогічні послуги (Глущенко, 2014: 52). За таких умов підвищується вірогідність консолідації різнопрофільних фахівців для досягнення спільної мети та реалізації завдань фізкультурно-оздоровчої роботи, а також іï включення до цілісного процесу абілітації/реабілітації (освітні, корекційно-розвиткові, позакласні, само- стійні, дистанційні заняття вдома самостійно або за підтримки батьків тощо).

Вищезазначені результати досліджень перебігу сервісної підтримки свідчать про необхідність і можливість організації комплексної фізкультурно-оздоровчої роботи з дітьми зі складними порушеннями розвитку у НРЦ, проте наукові розробки означеного спрямування відсутні.

Мета статті полягає в обгрунтуванні фізкультурно-оздоровчої програми в дітей середнього шкільного віку зі складними порушеннями розвитку.

Виклад основного матеріалу. Для досягнення поставленої мети були використані методи теоретичного рівня дослідження (аналіз, синтез, індукція, дедукція).

У дослідженні брали участь 90 дітей середнього шкільного віку зі складними порушеннями розвитку (порушення інтелекту та слуху). Експериментальна база дослідження: КЗ «Чернівецький обласний навчально-реабілітаційний центр № 1», КЗ «Київський навчально-реабілітаційний центр I-III ступенів № 6», К3 «Дніпропетровський навчально-реабілітаційний центр № 10», Калуський навчально-реабілітаційний центр Івано-Франківської обласної ради, КЗ «Теребовлянський навчально-реабілітаційний центр», КЗ «Київська загальноосвітня спеціальна школаінтернат I-III ступенів № 9», КЗО «Дніпропетровський багатопрофільний навчально-реабілітаційний ресурсно-методичний центр корекційної роботи та інклюзивного навчання», КЗ «Одеська спеціальна загальноосвітня школа-інтернат № 91 I-III ступенів» для глухих дітей, К3 «Херсонська спеціальна загальноосвітня школа-інтернат I-III ступенів», КЗ «Миколаївська спеціальна загальноосвітня школа-інтернат I-III ступенів № 6».

Комплексна, диференційована, багатофакторна система фізкультурно-оздоровчої роботи у НРЦ передбачала розроблення фізкультурнооздоровчої програми для дітей середнього шкільного віку зі складними порушеннями розвитку як складника експериментальної системи. Програма мала інноваційну спрямованість фізичної культури для означеної категорії дітей: за індивідуально-диференційованим підходом було розроблено фізкультурно-оздоровчі заняття, на яких 
було враховано особливості кардіореспіраторної системи, рівень соматичного здоров'я та фізичної підготовленості середніх школярів зі складними порушеннями розвитку. Зміст програми передбачав наявність спеціальних комплексів фізичних вправ, які сприяли фізичному розвитку та поліпшенню здоров'я дітей відповідно до порушень їхнього фізичного розвитку. Було включено такі засоби: танцювальну аеробіку, силові вправи, фітбол-аеробіку, йогу, стретчинг та дихальну гімнастику, а також додаткові предмети й устаткування (гантелі, м'ячі, скакалки, гімнастичні палиці, гумовий амортизатор), що сприяло ефективному вирішенню поставлених завдань та впливало на емоційний стан дітей середнього шкільного віку зі складними порушеннями розвитку.

Реалізація фізкультурно-оздоровчої програми здійснювалася протягом дев'яти місяців і поділялася на три послідовні періоди: підготовчий, тренувальний та підтримувальний.

За методикою Г. Апанасенко дітей середнього шкільного віку зі складними порушеннями розвитку було розподілено за рівнями соматичного здоров’я на низький, нижчий за середній, середній.

Змістом і завданнями підготовчого періоду (8 тижнів) виступили: адаптація організму дітей із складними порушеннями розвитку до оздоровчокорекційної роботи; ознайомлення 3 технікою виконання вправ танцювальної аеробіки, стретчінгу, силових вправ, дихальної гімнастики; створення позитивної налаштованості щодо занять фізкультурно-оздоровчого спрямування; активізація роботи кардіореспіраторної системи.

Змістом і завданнями тренувального періоду (16 тижнів) було: збільшення адаптаційних можливостей дітей зі складними порушеннями розвитку до навантаження, яке поступово зростало; закріплення техніки виконання танцювальної аеробіки, стретчінгу, фітбол-аеробіки, дихальної гімнастики; формування мотивації до систематичних занять за фізкультурно-оздоровчими програмами; поліпшення рухових здібностей; корекція постави та низького рівня фізичного здоров'я; сприяння поліпшенню функціонального стану серцево-судинної та дихальної систем.

Змістом і завданнями підтримувального періоду (12 тижнів) було: підтримання досягнутого рівня функціонування кардіореспіраторної системи середніх школярів зі складними порушеннями розвитку; формування техніки виконання вправ йоги, стретчінгу, фітбол-аеробіки, дихальної гімнастики; стимулювання мотивації до систематичних занять за індивідуальними, диференційованими фізкультурно-оздоровчими програмами; поліпшення рухових здібностей; нормалізація постави; підвищення рівня фізичного здоров'я; підвищення функціонального стану серцевосудинної та дихальної систем.

Для дітей середнього шкільного віку з низьким рівнем фізичного здоров'я в підготовчому періоді тривалість заняття за розробленою програмою становила 30-35 хвилин, у тренувальному 40-45 хвилин, у підтримувальному - 55-60 хвилин; інтенсивність фізичного навантаження становила відповідно 40-45, 45-50 та 50-55\% від резерву ЧСС.

Для дітей із нижчим за середній рівнем фізичного здоров'я в підготовчому періоді занять фізкультурно-оздоровчою програмою тривалість становила 35-40 хвилин, у тренувальному 45-50 хвилин, у підтримувальному - 60 хвилин; інтенсивність фізичного навантаження становила відповідно $45-50,50-55$ та 55-60\% від резерву ЧCC.

Діти із середнім рівнем фізичного здоров'я в підготовчому періоді займалися упродовж 40-45 хвилин, у тренувальному - 50-55 хвилин, у підтримувальному - 60 хвилин; інтенсивність фізичного навантаження у відповідних періодах становила $45-50,55-60$ та 60-70\% від резерву ЧСС.

У підготовчому періоді для дітей із низьким рівнем фізичного здоров'я вправи танцювальної аеробіки та силові вправи становили 30\% часу заняття; дихальні вправи та стретчинг - $20 \%$ часу. Для дітей із нижчим за середній рівень фізичного здоров'я на танцювальну аеробіку було відведено $40 \%$ часу, силові вправи - 30\%, стретчинг $-20 \%$, дихальні вправи $-10 \%$; із середнім рівнем відповідний розподіл засобів становив 40, 40, 20 та $10 \%$.

Під час тренувального періоду для дітей із низьким рівнем фізичного здоров'я на вправи фітбол-аеробіки було відведено 30\% часу, силові вправи - 40\%, стретчинг та дихальні вправи по 20\%; із нижчим за середній рівень - вправи степ-аеробіки, фітбол-аеробіки та стретчингу становили по 20\% часу, силові вправи $-40 \%$; iз середнім рівнем - вправи степ-аеробіки, фітболаеробіки та силові вправи становили по 30\% часу, стретчингу $-10 \%$. Блок-схема структури та змісту фізкультурно-оздоровчої програми представлена на рис. 1.

На підтримувальному періоді для дітей із низьким рівнем фізичного здоров'я на вправи фітболаеробіки було відведено $20 \%$ часу, степ-аеробіки $40 \%$, на силові вправи - 30\%, стретчинг - 10\%; iз нижчим за середній рівень відповідні вправи розподілилися таким чином: 20, 30, 40 та 10\%. 


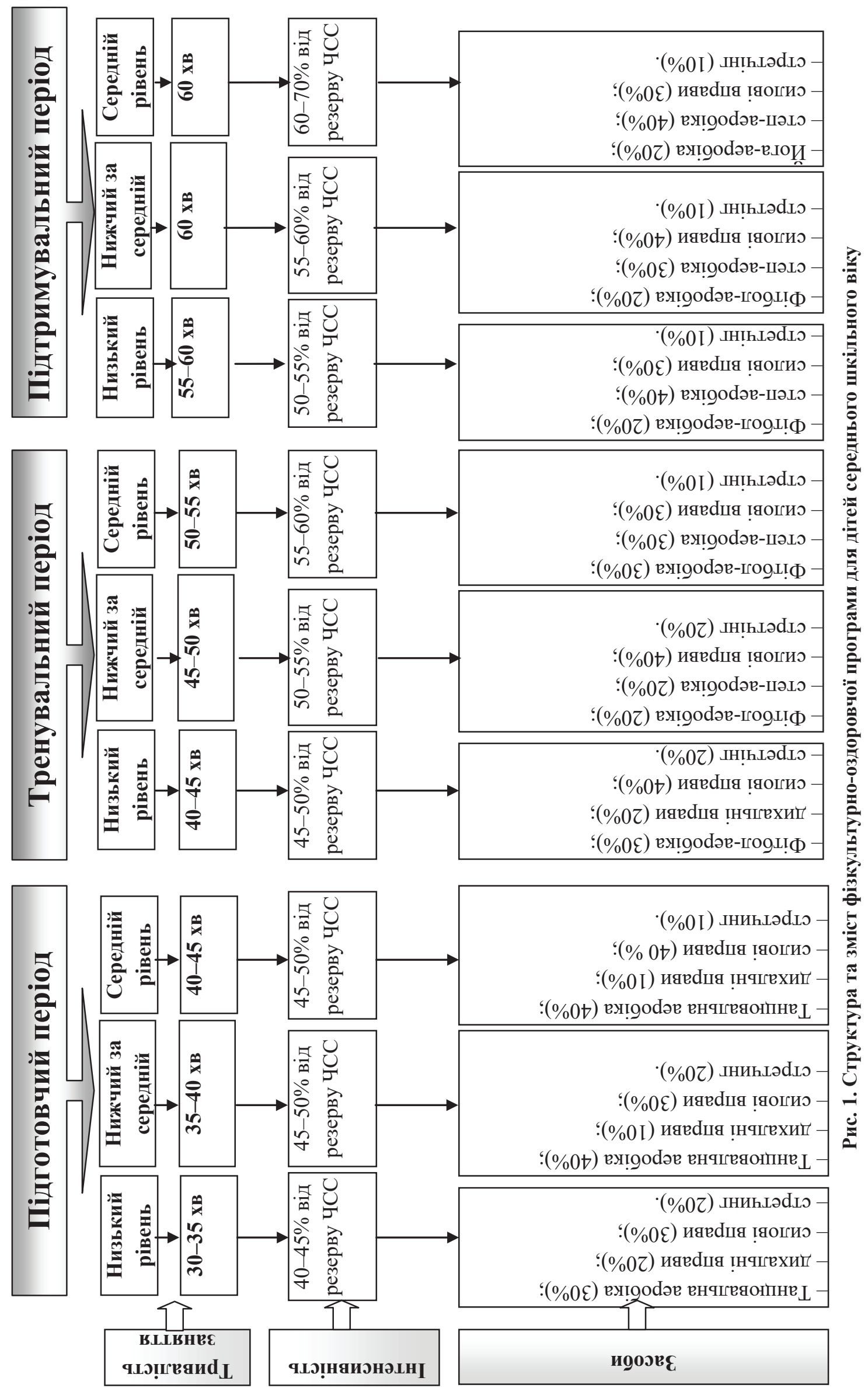


Для дітей із середнім рівнем фізичного здоров'я на цьому етапі йога-аеробіка становила $20 \%$ часу, степ-аеробіка $-40 \%$, силові вправи $-30 \%$, стретчинг $-10 \%$.

Навчання дітей середнього шкільного віку вправ танцювальної аеробіки та степ-аеробіки проводили в такій послідовності: вивчення однієї вправи, потім послідовне об'єднання кількох вправ у серію, потім формували певну комбінацію із серії вправ.

Під час навчання окремих серій вправ та комбінацій застосовували переважно метод лінійної прогресії та від «голови до хвоста», адже саме такі способи були більш прийнятними для засвоєння дітьми середнього шкільного віку зі складними порушеннями розвитку.

У разі вивчення нових елементів танцювальної аеробіки за лінійним методом багаторазово повторювали окремий елемент, а потім намагалися його ускладнювати збільшенням темпу виконання, використанням додаткового устаткування чи додаванням рухів руками.

У разі застосування методу «від «голови до хвоста» окремо розучували 2 вправи, потім їх поєднували, вивчали третю, а потім поєднували їі 3 передостанньою. Цей метод навчання був більш складним для дітей, його використовували переважно на підтримувальному етапі, коли вже основна база вправ була засвоєна учнями.

Демонстрація всіх вправ танцювальної аеробіки та степ-аеробіки проводилася у дзеркальному зображенні, що дозволяло дітям легше зрозуміти техніку виконання окремих вправ і уникати помилок.

Навчання вправ степ-аеробіки розпочинали 3 висоти сходинки не більш ніж 10 см на тренувальному періоді, а на підтримувальному поступово збільшували до 15-20 см залежно від рівня фізичного здоров’я дитини зі складними порушеннями розвиту.

Степ-платформу використовували не тільки для виконання аеробних вправ, але й для виконання вправ силового спрямування (віджимання зі степу 3 різним вихідним положенням рук; укріплення м'язів черевного пресу - лежачи на спині чи боці; м'язів спини та сідниць - лежачи животом на степі). Навантаження на заняттях степ-аеробікою варіювалося залежно від обраної висоти платформи, темпу та складності виконуваних рухів, кількості стрибків, використання обтяжень.

На перших заняттях зосереджували увагу учнів на техніці безпеки виконання вправ, а саме униканні надмірного нахилу вперед чи прогину назад у поперековому відділі хребта, згинанні ніг у колінному суглобі під час підйому на степ; під час підйому на степ цілком ставити стопу на центральну частину платформи.

Під час виконання вправ фітбол-аеробіки інтенсивність їх також варіювалася залежно від рівня фізичного стану дитини. На перших заняттях навчали дітей підтримання балансу на фітболі у вихідному положенні сидячи, лежачи животом та спиною. Такі різноманітні вихідні положення сприяли залученню глибоких м'язів спини для підтримання рівноваги, а також розвитку координаційний здібностей, вестибулярного апарату i формуванню навички правильної постави.

В основній частині заняття виконували вправи для розвитку м'язів черевного преса, зміцнення м'язів спини, косих м'язів тулуба, шиї, формування навичок рівноваги та правильної постави, збільшення рухливості хребта. Розмір фітбола підбирався індивідуально залежно від зросту та маси дитини зі складними порушеннями розвитку. Давали можливість вибору дітям кольору м'яча залежно від власних побажань. Для різноманітності занять фітбол-аеробікою в дітей зі складними порушеннями розвитку застосовувалися рухливі ігри з фітболом. Наведемо приклади деяких із них:

1. «Бездомний зайчик». Фітболи в довільному напрямі розташовуються в різних кінцях зали 3 кількістю, щоб була меншою від кількості учасників. Усі учасники є «зайцями», які за командою починають бігати по залу. Після проголошення команди: «Усі в дім!» гравці сідають на будь-який iз м'ячів. «Бездомним зайцем» $\epsilon$ той учасник, що не зайняв м'яч. Він вибуває із гри. У кожній наступній грі кількість м'ячів скорочується на один.

2. Естафета «Цвіркуни». Учасники поділяються на дві команди, розташовуються в колоні, сидячи на фітболах перед стартом. За командою починають виконувати стрибки на м'ячах на установлену відстань 5-10 метрів уперед. Коли перший гравець перетне стартову лінію та доторкнеться рукою до наступного учасника, то він починає стрибати. Виграє команда, яка першою закінчить естафету. Такі естафети сприяли збільшенню функціонального резерву кардіореспіраторної системи, витривалості, координації та сили м'язів ніг у дітей зі складними порушеннями розвитку.

3. Прогнися й передай м'яч. Діти сідали на підлогу в колону по одному на відстані 1 м один від одного. За командою діти виконували прогин у поперековому відділі хребта та передавали фітбол 
над головою до кінця колони. Останній гравець у колонні, коли одержав фітбол, сідав першим. Переможцем ставала та команда, яка найшвидше займала своє вихідне положення.

У заключній частині заняття незалежно від рівня фізичного здоров’я й етапу занять виконувалися вправи стретчингу, які сприяли збільшенню мобільності в суглобах, еластичності м'язів та зняттю напруження після отриманого навантаження в основній частині заняття.

Висновки. У рамках фізкультурно-оздоровчої роботи в навчально-реабілітаційному центрі розроблено інноваційну фізкультурно-оздоровчу програму для дітей середнього шкільного віку зі складними порушеннями розвитку, яка відрізнялася диференційованим підходом у регламентації фізичного навантаження та підборі засобів відповідно до рівня фізичного здоров'я дитини зі складними порушеннями розвитку й етапу занять.

Перспективи подальших досліджень передбачають експериментальну апробацію фізкультурно-оздоровчої програми для дітей середнього шкільного віку щодо поліпшення функціонального стану серцево-судинної та дихальної систем.

\section{СПИСОК ВИКОРИСТАНИХ ДЖЕРЕЛ}

1. Бобренко І. В. Розвиток просторового орієнтування у молодших школярів із складними порушеннями психофізичного розвитку: реалізація у навчальній програмі з фізичної культури. Освіта осіб з особливими потребами: иляхи розбудови : збірник статей молодих учених. 2011. Вип. 2. С. 23-32.

2. Глушенко К. О., Гладких Н. В. Актуальні проблеми навчання та виховання дітей з комплексними порушеннями розвитку в Україні. Науковий часопис Національного педагогічного університету імені М. П. Драгоманова. Серія 19 «Корекиійна педагогіка та спеціальна психологія». Київ, 2014. Вип. 26. С. 52-57.

3. Лещій Н. П. Стан фізкультурно-оздоровчої роботи в сучасній практиці освітньо-реабілітаційного центру для дітей зі складними порушеннями розвитку. Науковий вісник Південноукраӥнського національного педагогічного університету імені К. Д. Уиинського. Серія «Педагогічні науки». 2020. № 1 (30) . С. 99-106.

4. Лещій Н. П. Теоретико-методичні основи фізкультурно-оздоровчої роботи з дітьми зі складними порушеннями розвитку в умовах освітньо-реабілітаційного центру : монографія. Одеса : ПНПУ, 2020. 304 с.

5. Ляхова I. М. Теоретико-методичні основи корекції рухової сфери дітей зі зниженим слухом засобами фізичного виховання : афтореф. дис... докт. пед. наук: 13.00.03. Київ, 2006. 42 с.

\section{REFERENCES}

1. Bobrenko I. V. Rozvytok prostorovoho oriientuvannia u molodshykh shkoliariv iz skladnymy porushenniamy psykhofizychnoho rozvytku: realizatsiia u navchalnii prohrami z fizychnoi kultury [Development of spatial orientation in junior schoolchildren with complex disorders of psychophysical development: implementation in the curriculum of physical culture]. Osvita osib z osoblyvymy potrebamy: shliakhy rozbudovy: zb.statei molodykh vchenykh, 2011, Vyp. 2, pp. 23-32 [in Ukrainian].

2. Hlushenko K. O., Hladkykh N. V. Aktualni problemy navchannia ta vykhovannia ditei z kompleksnymy porushenniamy rozvytku v Ukraini [Current problems of education and upbringing of children with complex developmental disorders in Ukraine]. Naukovyi chasopys NPU imeni M. P. Drahomanova. Seriia 19 : Korektsiina pedahohika ta spetsialna psykholohiia - Scientific journal of NPU named after M. P. Drahomanov. Series 19: Correctional pedagogy and special psychology, 2014, 26, 52-57 [in Ukrainian].

3. Leshchii N. P. Stan fizkulturno-ozdorovchoi roboty v suchasnii praktytsi osvitno-reabilitatsiinoho tsentru dlia ditei zi skladnymy porushenniamy rozvytku [The state of physical culture and health work in the modern practice of the educational and rehabilitation center for children with complex developmental disorders]. Naukovyi visnyk Pivdennoukrainskoho natsionalnoho pedahohichnoho universytetu imeni K. D. Ushynskoho. Pedahohichni nauky, 2020, № 1 (30), pp. 99-106 [in Ukrainian].

4. Leshchii N. P. Teoretyko-metodychni osnovy fizkulturno-ozdorovchoi roboty z ditmy zi skladnymy porushenniamy rozvytku v umovakh osvitno-reabilitatsiinoho tsentru [Theoretical and methodical bases of physical culture and improving work with children with difficult disturbances of development in the conditions of the educational and rehabilitation center]: monohrafiia. Odesa : PNPU, 2020, 304 s. [in Ukrainian].

5. Liakhova I. M. Teoretyko-metodychni osnovy korektsii rukhovoi sfery ditei zi znyzhenym slukhom zasobamy fizychnoho vykhovannia [Theoretical and methodological bases of correction of the motor sphere of children with hearing impaired means of physical education]: Extended abstract of Doctor's thesis, Kyiv, 2006, 42 s. [in Ukrainian]. 